\title{
子宮卵管造影における患者皮䖉線量と画質の最適化
}

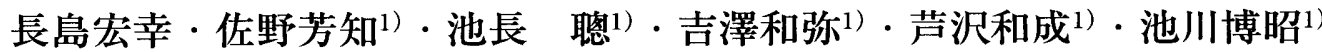

縛

線量の低減と画質の向上についての考え方は大きく 二つに集約でき，線量を変えずに画質を向上させるこ
とと，画質は一定に保ちながら線量を低減させること に分けられ相反関係となっている11.これら画質と線 量の最適化 ${ }^{2)}$ にって，検査目的をよく理解し，画質

\section{Optimization of Patient Skin Dose and Image Quality for Hysterosalpingography (HSG)}

\author{
HIROYUKI NAGASHIMA, YOSHITOMO SANO, ") SATOSHI IKENAGA, " KAZUYA YOSHIZAWA, ") \\ KAZUNARI ASHIZAWA, ${ }^{\prime)}$ and HIROAKI IKEGAWA') \\ Department of Radiology. Yamanashi Medical University Hospital(Present address: Department \\ of Clinical Radiology, Gunma Prefectural College of Health Sciences) \\ 1) Department of Radiology, Yamanashi Medical University Hospital
}

Received June 19, 2001; Revision accepted Nov. 15, 2001; Code No. 621

\section{Summary}

Because HSG is an x-ray examination for the genital glands, it is very important to reduce $\mathrm{x}$-ray exposure to the patient. However, reducing exposure decreases image quality and causes a lack of optimization in image quality and dose. In computed radiography, image density does not depend on the dose exposed, and appropriate images can be obtained by adjusting the image processing parameters. Therefore, computed radiography can reduce $x$-ray exposure and improve image quality. In this study, we performed HSG using low-dose radiography with computed radiography $(C R)$ systems and evaluated a simple procedure for reducing exposure dose while maintaining image contrast by changing radiation quality and adding filters. We also examined ways to reduce dose by using both procedures. We found that low-dose radiography using the CR system could increase the $S$ value to 1,200 from visual evaluation and could reduce by patient skin dose by $58 \%$. To maintain the image contrast by changing radiation quality, the radiographic condition that was the same as $80 \mathrm{kV}$ without the filter was a $72 \mathrm{kV}$ tube voltage with $0.3 \mathrm{~mm}$ copper and $1 \mathrm{~mm}$ aluminum filter, and it could reduce patient skin dose by $57 \%$. In HSG examination, patient skin dose could be reduced by $82 \%$ by low-dose $x$-ray radiography using a CR system and by adding a filter, and it could offer images that showed no loss of diagnostic quality. Therefore, it could be said that our procedure for HSG is useful for the optimization of image quality and dose.

Key words: Hysterosalpingography (HSG), Skin dose reduction, Computed radiography system, Added filter, Image quality 
Table 1 CR image processing parameters used in HSG.

\begin{tabular}{cc|cc}
\hline GA & 1.1 & RN & 3 \\
GT & D & RT & Q \\
GC & 0.6 & RE & 1.0 \\
GS & 0.2 & S-shift & 1.0 \\
& & C-shift & 1.0 \\
\hline
\end{tabular}

と線量のどちらを重視するか熟知したうえで撮影条件 を決定することは重要である。

子宮卵管造影(hysterosalpingography：以下, HSG $)^{3,4)}$ は，子宮抢よび卵管腔内に造影剂を注人し，子宮の位 置, 形, 内腔の状態や卵管の状態(卵管柾通性, 卵管の 癒着)を描出する検榃法で，抢もに不妊の場合の卵管通 過性の診断に対して行われている.HSGは, 生殖腺に 対するX線検査であり，放射線障害における確率的影 響のリスクを下げるためにできる限り線量低減を行う ことは非常に意義がある。しかし，X線画像システム に执いて線量を大幅に低減すると画質(診断能)の低下 は避けられず，最適化が損なわれてしまう。

近年，X線診断領域の分野ではディジタル化が進 み, 一般撮影に拉いて従来の増感紙一フィルム系 $(\mathrm{S} / \mathrm{F}$ 系)に代わり，輝尽性蛍光体によるimaging plate (IP)を 用いたcomputed radiography (以下, CR) システム5, 6) やX線平面検出器 (フラットパネルディテクタ : FPD $)^{7-9)}$ が記録媒体として暳及している。これらディジタル画 像の特長として, 写真濃度が線量に依存しないこと や, 画像処理(階調処理や周波数処理)のパラメー夕を 変化させて適切な画像が提供できることから線量を低 減でき，さらに画質の改善をはかることが可能となっ た。過去の研究からCRシステムの使用により, 線量 低減が重要視されている計測や存在診断などを目的と した撮影(骨盤計測・小罗股関節・全准撮影)にて, 画質を診断に支障のないレベルに保ち, 被曝低減を行 つた報告はされている10-12)。また，撮影管電压と付加 フィルタにてX線スペクトルの適正化を行い, 画像コ ントラストを低下させることなく被曝低減を行った報 告もされている(3).

今回，CRシステムを使用してHSGに扔ける低線量 撮影を行い，X線量子ノイズによる画質への影響につ いて評価・検討した。 また，撮影管電庄と付加フィル タにより線質を変化させ14-16)，画像コントラストを-.. 定に保ち, X線スペクトルの適正化にて効率よく線量 を低減させることについても検討し, 両手法の併用に て大幅な被曝低減を試みたので報告する。

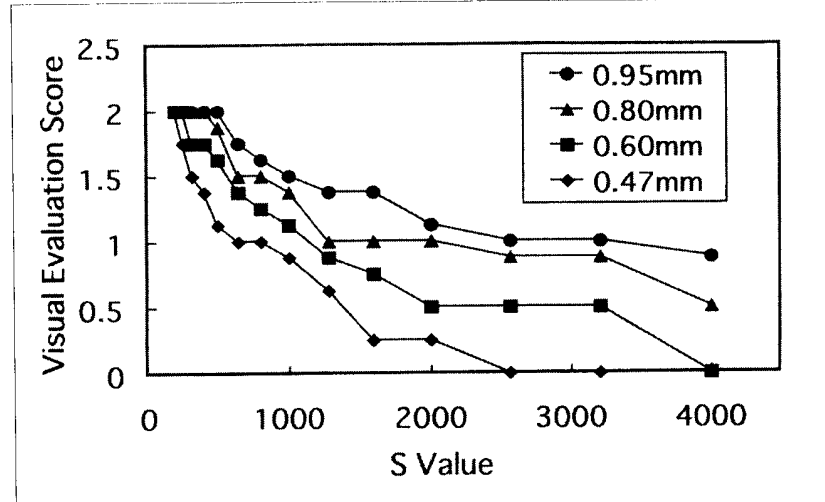

Fig. 1 Visual evaluation of imitation salpinx radiographic image according to $S$ value.

\section{1. 方法および結果}

\section{1-1 使用機器}

X線発生装置：KXO-50G (株式会社東芝製)

X線管：DRX-3535HD 総滤過 $2.3 \mathrm{mmAl}$

(株式会社東芝製)

線量計：UNIDOS線量計 (PTW社製)

プローブ：JARP形0.6cc指頭形電離箱 30006

(PTW社製)

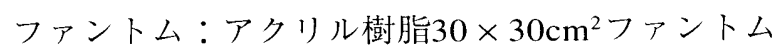

解像力チャート：Type 2 No 50946 空間周波数1.0 $\sim 4.86 \mathrm{Lp} / \mathrm{mm}$ (極光株式会社製)

濃度計：Mode1301

(富士フイルムメディカル株式会社製)

画像処理装置：FCR9000

(富士フイルムメディカル株式会社製)

X線スペクトルアナライザ：RAMTEC 413型

(東洋メディック株式会社製)

当院に扔けるHSG検査数は，1998年～2000年の過 去 3 年間において年間平均約60例で, 年歯命20４0歳代 前半 (平均31.6歳) の患者を対象として行われている.

当院にてCT検査を行った年齢20４0歳代女性の骨盤 腔レベルのアキシャル画像から被写体厚を測定した結 果, 平均 $16.96 \mathrm{~cm}$ となり, 今回実験に使用するアクリ

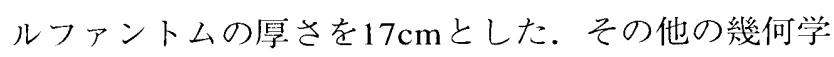
的条件は, source image receptor distance (SID) $100 \mathrm{~cm}$, 照射野 $20 \times 20 \mathrm{~cm}^{2}$, 散乱線除去用グリッド $10: 1(40$ 本 $/ \mathrm{cm}$, 中間物質アルミニウム)とした。付加 フィルタの種類は，入手が簡単で被曝低減効果が高い 銅 (以下, $\mathrm{Cu}$ ), アルミニウム (以下, $\mathrm{Al}$ ) を使用し, 厚 さを $\mathrm{Cu}$ フルタ $0.1 \sim 0.5 \mathrm{~mm}$ まで $0.1 \mathrm{~mm}$ 扮きに, $\mathrm{Al}$ フ イルタ 1 - 5mmまで $1 \mathrm{~mm}$ 拈きに変化させて行った。撮 影はすべてCRシステムにて行った。使用したIPは四 ツ切サイズのST-Vである。画像読み取りについて は, manualモードにてL值1.6に固䇥, 1 画像出力とし 


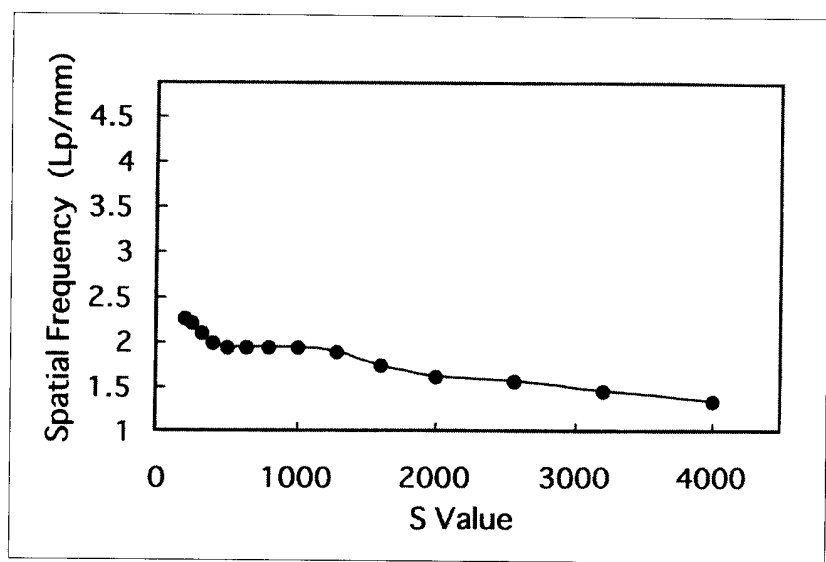

Fig. 2 Visual evaluation of resolution test chart radiographic image according to $S$ value.

たＬ值を1.6にしたのは，臨床にてautoモードで処理 した結果，ほとんどの画像が值1.6となったからであ る.フィルム出力の処理パラメータは, 当院において 臨床に用いているHSG検査用のものを使用した。使用 したパラメータをTable 1に示す.今回の実験は, 当院 におけるHSGの平均的な撮影条件である $80 \mathrm{kV}$ ， $400 \mathrm{~mA}, 0.028 \mathrm{sec}(\mathrm{S}$ 值500) を基準条件として行った。 透視条件についてはABC制御を使用，管電流 $1.0 \mathrm{~mA}$, 管電压は使用した付加フィルタの厚さにて自動調節さ れた管電压を使用して行った。線量測定にはUNIDOS 線量計とPTW社製0.6ccチェンバを使用した。

\section{1-2 画質の評価}

\section{1-2-1 低線量撮影による評価}

内径の異なるサーフロ留置針0.95, 0.8, 0.6, $0.47 \mathrm{~mm}$ にヨード造影剤(アミドトリゾ酸 $292 \mathrm{mg} / \mathrm{ml}$ )を 満たし，それを模擬卵管としてアクリルファントム $17 \mathrm{~cm}$ の中間に並べて配置した。当院にて使用してい る管電圧 $80 \mathrm{kV} /$ 付加フィルタなし (以下, $80 \mathrm{kV}(-)) に$ て，管電流 $400 \mathrm{~mA}$ 一定，S值が200～2,000となるよう 撮影時間を変化させて撮影した17). フィルム出力の 際，アクリルファントムの写真濃度が1.00になるよj 設定した．その画像を診療放射線技師 4 名にて視覚評 価した。評定法は 3 段階評価にて，模擬卵管が管状 に見える」を 2 点，「なんとか管状に見える」を 1 点, 「管状とは判断できない」を０点とした。

模擬卵管の視覚評価の結果をFig. 1に示す。評価は $\mathrm{S}$ 值が上昇するに従い低下し, 最小径の模擬卵管 $0.47 \mathrm{~mm}$ では急激に低下した．「なんとか管状に見え る」という評価点 1 において最小径の模擬卵管は，S值 800 がしきい値となり，模擬卵管 $0.6 \mathrm{~mm}$ ではS 值 1,000 〜1,200がしきい值となった．「管状とは判断できな い」という評価点 0 では, 最小径の模擬卵管で, $\mathrm{S}$ 值

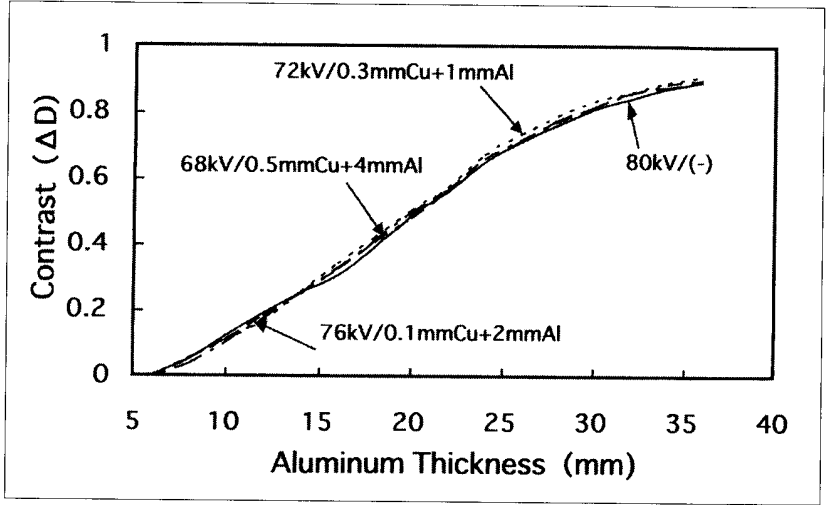

Fig. 3 Image contrast by radiographic condition with various combinations of tube voltage and added filter according to aluminum thickness.

2,600がしきい值となつた.

同様に解像力チャートをアクリルファントムの中間 に配置し，前述した撮影条件にて撮影を行い視覚評価 した。

解像力チャートでの視覚評価の結果をFig. 2に示 す. 空間周波数はS值が500になるまで急激に低下した が, 空間周波数 $2 \mathrm{Lp} / \mathrm{mm}$ において $\mathrm{S}$ 值 1,200 まで一定と なり，それ以上のS值では徐々に低下した。

1-2-2 画像コントラストの測定

アルミニウムステップ $(2 \mathrm{~mm}$ 厚間隔，20段 $)$ をクリ ルファントムの上に置き, $80 \mathrm{kV}(-)$ にて画像コントラ ストを測定した，管電圧76，72，68kVにて，付加フ イルタ $\mathrm{Cu} \cdot \mathrm{Al}$ の厚さを種々に変化させてアルミニウ ムステップを撮影し, 画像コントラストが $80 \mathrm{kV}(-)$ と 同様になる付加フィルタの厚さを決定した，撮影条件 は，管電圧と付加フィルタによる各組み合わせにてS 值を一定とし，管電流 $400 \mathrm{~mA}$ 一定，撮影時間をアルミ ニウムステップの厚さ $22 \mathrm{~mm}$ の写真濃度が 1.00 になる よう設定した，濃度測定は，画像をフィルムに出力す るオーバーオールにて濃度計を使用して行った。

管電圧と付加フィルタの組み合わせによる撮影条件 にて，画像コントラストを一定にした結果をFig. 3に 示す. 緃軸の画像コントラスト比 $(\Delta \mathrm{D})$ はアルミニウ ムステップの厚さ $6 \mathrm{~mm}$ の濃度をバックグラウンドとし て計算し表示した. $80 \mathrm{kV}(-)$ と画像コントラストが同 一になる管電圧と付加フィルタの組み合わせは, $76 \mathrm{kV}$ で0.1mmのCuフィルタと $2 \mathrm{~mm}$ の $\mathrm{Al}$ フィタの組 み合わせ (以下, $76 \mathrm{kV} / 0.1 \mathrm{mmCu}+2 \mathrm{mmAl}), 72 \mathrm{kV} /$ $0.3 \mathrm{mmCu}+1 \mathrm{mmAl}, 68 \mathrm{kV} / 0.5 \mathrm{mmCu}+4 \mathrm{mmAl}$ となり, 各撮影条件ともほぼ同等となった。

\section{1-2-3 透視による評価}

HSGは，盲目にて行う方法(撮影のみ)と透視にて流 速や流量，造影剂注入にかかる圧力などを確認しなが 


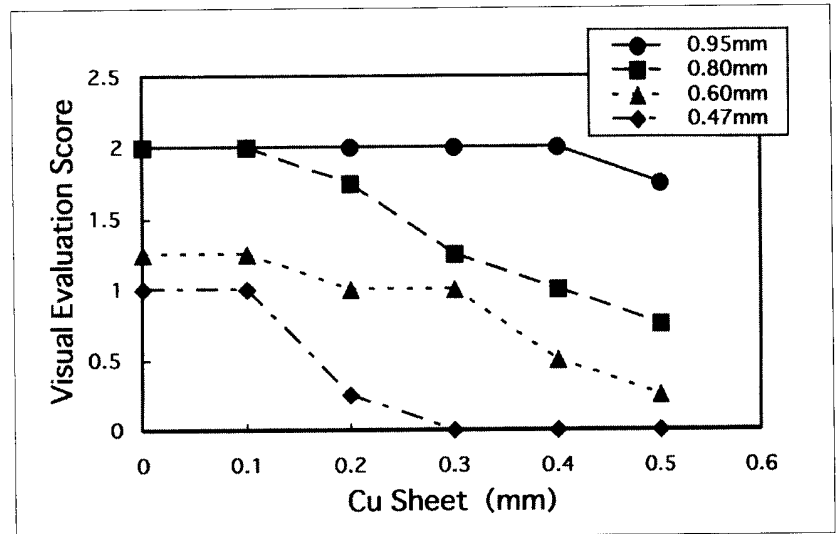

Fig. 4 Visual evaluation of imitation salpin $x$ under $x$-ray fluoroscopy.

Table 2 Exposure conditions and effective $x$-ray energy obtained using the radiographic condition with various combinations of tube voltage and added filter.

\begin{tabular}{cccc}
\hline $\begin{array}{c}\text { Tube voltage } \\
(\mathrm{kV})\end{array}$ & $\begin{array}{c}\text { Additional filter } \\
\text { copper and aluminum } \\
(\mathrm{mm})\end{array}$ & $\begin{array}{c}\text { Time } \\
(\mathrm{sec})\end{array}$ & $\begin{array}{c}\text { Effective energy } \\
(\mathrm{keV})\end{array}$ \\
\hline 80 & - & 0.028 & 33 \\
76 & $0.1+2$ & 0.056 & 40 \\
72 & $0.3+1$ & 0.084 & 42 \\
68 & $0.5+4$ & 0.280 & 48 \\
\hline
\end{tabular}

ら行う方法(透視と撮影)とがあり，最近では診断能の 向上がはかれる透視を用いて行う方法が主として行わ れている4).しかし，透視により線量が増加し，生殖 腺に対するX線検査であるため線量を低減することは 重要である。

そこでSID $100 \mathrm{~cm}$, 照射野 $20 \times 20 \mathrm{~cm}^{2}$, アクリルフ

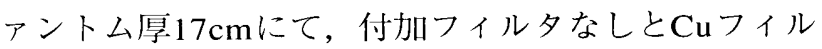
夕を0.1〜0.5mmまで $0.1 \mathrm{~mm}$ おきに付加した時の透視 管電圧を求めた。1-2-1にて使用したヨード造影剂の 人った模擬卵管をアクリルファントムの中間に配置 し，各透視管電压に扮ける画像をX線テレビモニ夕上 にて視覚評価した．評定法は1-2-1と同様，3段階評価 とし，診療放射線技師 4 名にて行った。

透視に抢ける模擬卵管の視覚評価の結果をFig. 4に 示す。透視管電圧は $\mathrm{Cu}$ フィルタなし〜0.5mmまで $0.1 \mathrm{~mm}$ おう付加により，90，92，95，98，101， $104 \mathrm{kV}$ となった。評価は最大径の模擬卵管 $0.95 \mathrm{~mm}$ 除くと0.1 $\mathrm{mm}$ より厚いCuフィルタを付加することによ り低下した。「なんとか管状に見える」という評価点 1 において，模擬卵管 $0.47 \mathrm{~mm}$ で $0.1 \mathrm{~mm}$ ，模擬卵管 $0.6 \mathrm{~mm}$ で $0.3 \mathrm{~mm}$ のCuフィルタがしきい值となった。

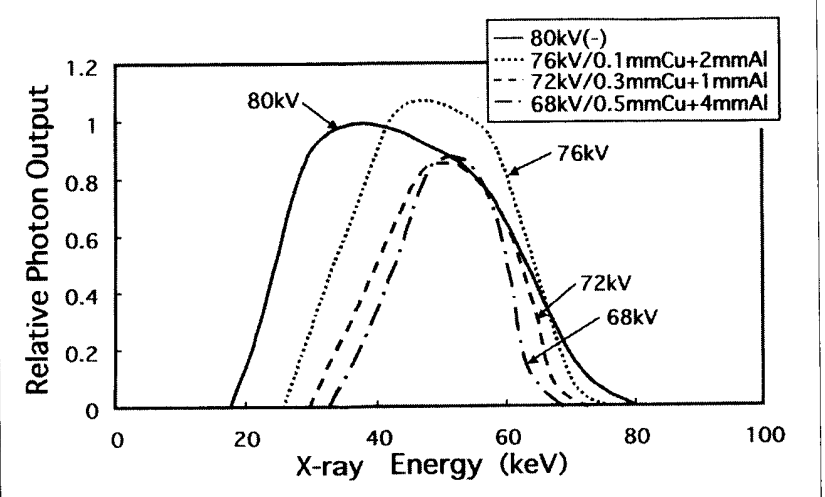

Fig. $5 \mathrm{X}$-ray spectra obtained using the radiographic condition with various combinations of tube voltage and added filter.

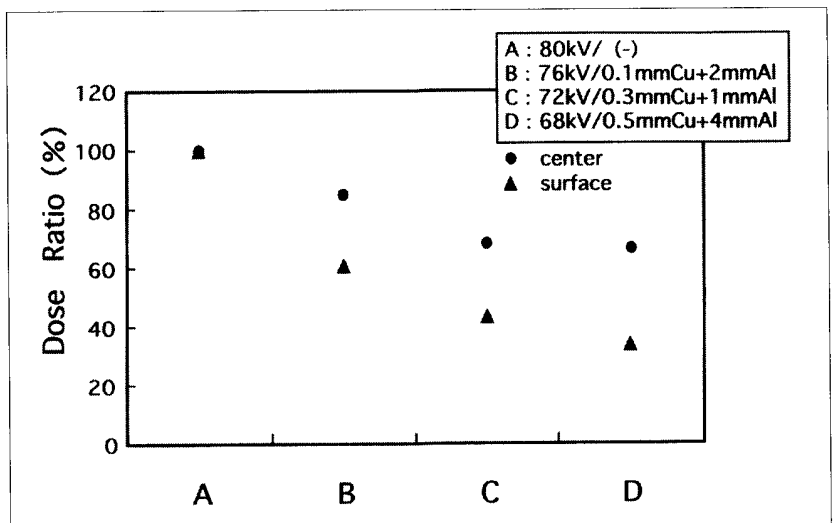

Fig. 6 Absorbed dose ratio of surface and center of the phantom obtained using the radiographic condition with various combinations of tube voltage and added filter.

\section{1-3 実効エネルギー}

1-2-2にて求めた管電压と付加フィルタの組み合わ せによる撮影条件にて，アルミニウム半価層を測定 し，これから実効エネルギーへ変換した。換算には Seltzer \& Hubbellの表を用いた18).

管電压と付加フィルタを組み合わせた撮影条件にお ける撮影時間と実効エネルギーをTable 2 に示す．撮影 時間は管電流400mAを一定とし，80kV(-)を基準にす ると，管電圧を下げ付加フィルタを使用することによ り2〜10倍長くなった。実効エネルギーは $80 \mathrm{kV}(-)$ で $33 \mathrm{keV}$ と一番低く, 付加フィルタを使用した組み合わ せでは，7〜15keV高くなった。

\section{1-4 X線スペクトルの測定}

半導体型検出器CdZnTeを用いたX線スペクトルア ナライザを使用し，Table 2に扔ける撮影条件でのX線 スペクトルを測定した。X線管球焦点- CdZnTe検出 器間距離 $500 \mathrm{~cm}$, 検出器のコリメータは, 焦点側に穴 径 $0.2 \mathrm{~mm}$, 検出器側に穴径 $0.1 \mathrm{~mm}$ のタングステン製板 


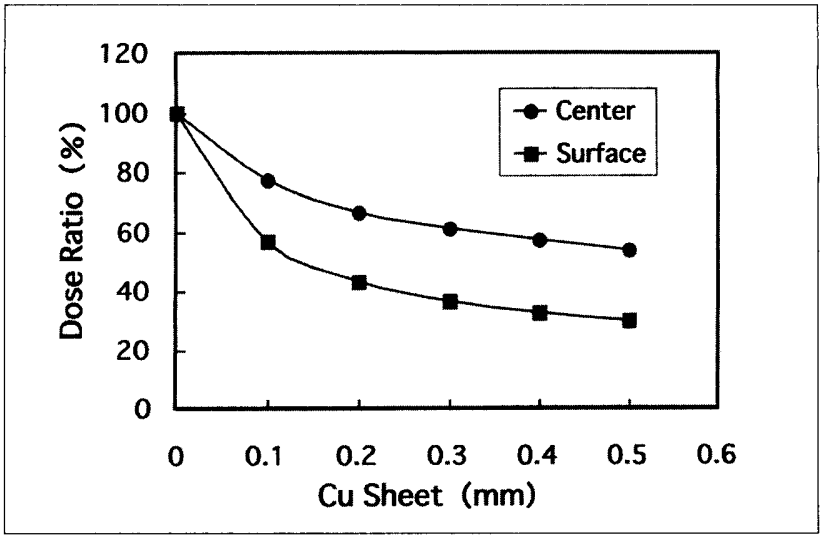

Fig. 7 Absorbed dose ratio of surface and center of the phantom obtained by $x$-ray fluoroscopy according to the thickness of the copper.

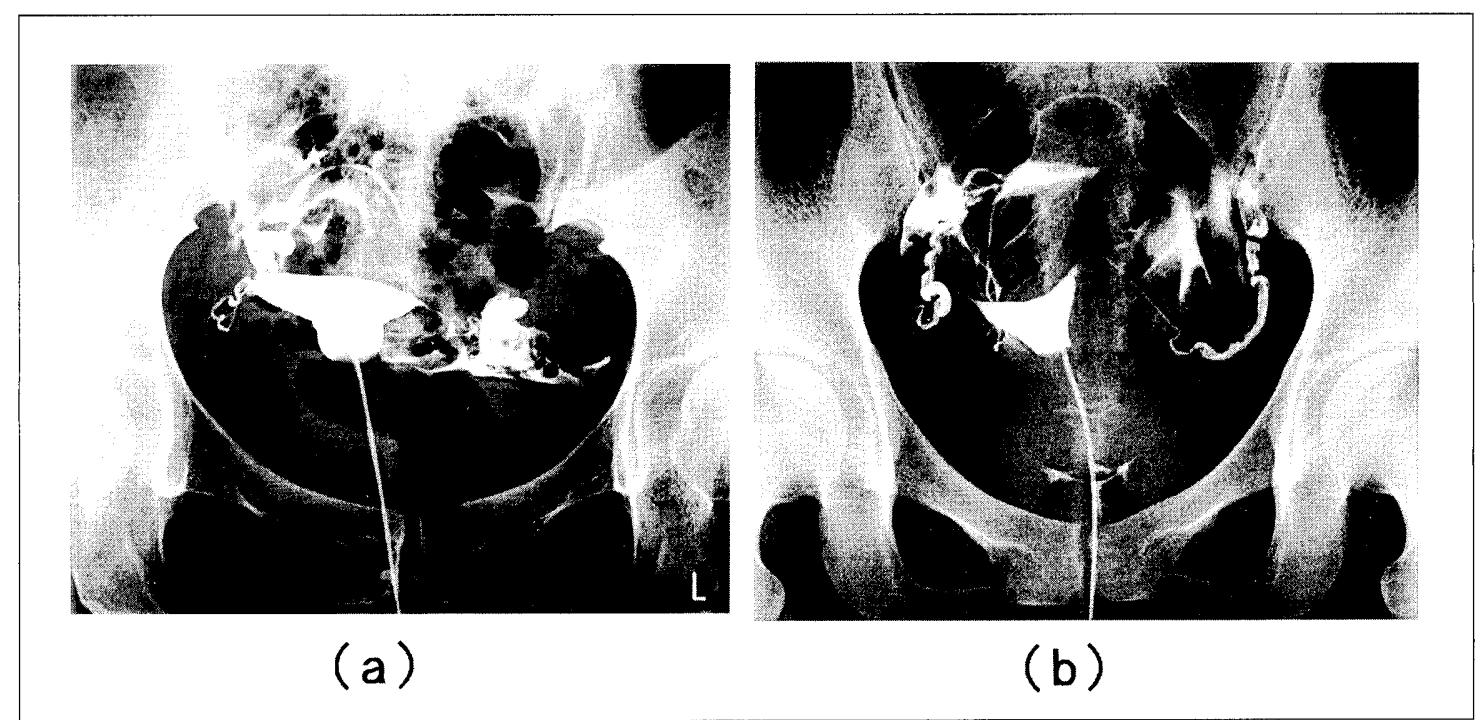

Fig. 8 HSG images taken under $80 \mathrm{kV}$ tube voltage without filter (a) and $72 \mathrm{kV}$ with $0.3 \mathrm{~mm}$ copper filter and $1 \mathrm{~mm}$ aluminum filter(b).

$(\phi 16 \mathrm{~mm}$ ，厚さ $2.0 \mathrm{~mm})$ を装着し，検出率を約 3,000counts/secにして行った。スペクトル補正はstripping法を使用した.

Table 2における撮影条件でのX線スペクトルの測定 結果をFig. 5に示す．縦軸は, $80 \mathrm{kV}(-)$ でのX線光子検 出数のピーク值を 1 として示している. $80 \mathrm{kV}(-)$ に対 して各撮影条件ともに管電圧を下げることにより高エ ネルギー成分が生じなくなり，低エネルギー成分では $80 \mathrm{kV}($-)に比べ $72 \mathrm{kV} / 0.3 \mathrm{mmCu}+1 \mathrm{mmAl}$ で大きくカッ

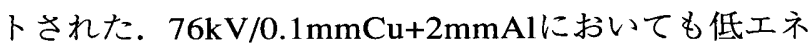
ルギー成分の減少がみられるが，X線エネルギーが41 〜 66keVの領域で $80 \mathrm{kV}(-)$ よりも光子検出数が上昇し た.

\section{1-5 線量測定 \\ 1-5-1 撮影線量の測定}

Table 2に打ける撮影条件にて，ファントム表面 $(\mathrm{SSD} 83 \mathrm{~cm})$ とファントム内 $(\mathrm{SCD} 91.5 \mathrm{~cm})$ の吸収線量 を測定した。

Table 2における撮影条件でのファントム表面とファ ントム内の吸収線量低減率の結果をFig. 6に示す. $80 \mathrm{kV}(-)$ の線量を基準にすると, ファントム表面で約 39〜66\%低減した。フフントム内においては約15３2 \%低減したが，0.3mmCu+1 mmAlより厚いフィルタを 付加してもほとんど変化はみられなかった。

\section{1-5-2 透視線量の測定}

1-2-3にて求めた各透視管電圧におけるファントム 表面とファントム内の吸収線量を測定した。

注 ）ボランティアには検査内容を詳細に説明し，十分に理解していただいたうえで同意を得た。 なお，この写真は検査過程での1枚であり， 撮影枚数および線量はこの研究のために増えていない. 

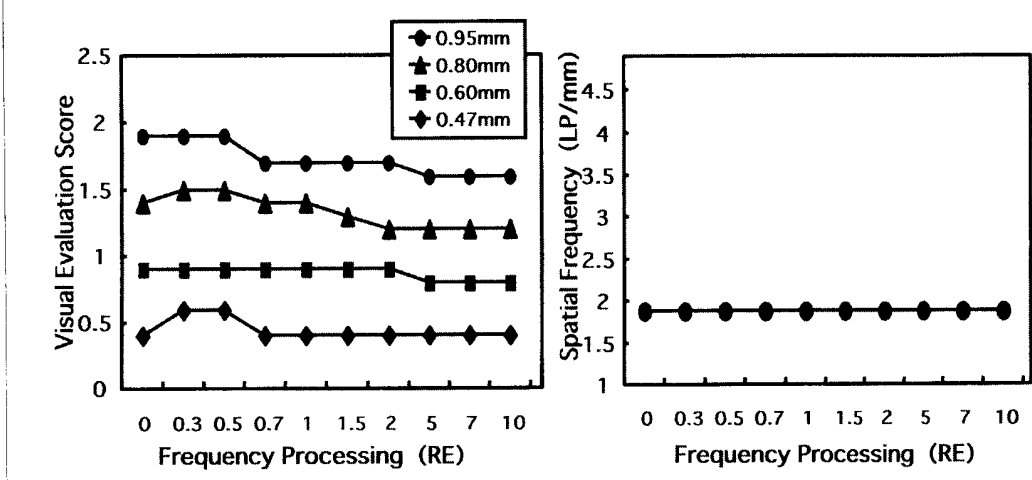

Fig. 9 Visual evaluation of the radiographic image of imitation salpinx and resolution test chart with frequency processing.

透視条件におけるファントム表面とファントム内の 吸収線量低減摔の結果をFig. 7に示す。Cuフィル夕の 厚さが增加するに従い低減し，ファントム表面に扔い て約 $43 \sim 70 \%$ 低減した。

以上の結果から，患者ボランティアのHSGの写真を Fig. 8に示す滥. ボランティアの写真は $80 \mathrm{kV}(-) / \mathrm{S}$ 值 500 と $72 \mathrm{kV} / 0.3 \mathrm{mmCu}+1 \mathrm{mmAl} / \mathrm{S}$ 值1,200の撮影条件に て行ったが，72kV/0.3mmCu+1 mmAlで撮影した方が (Fig. 8b)，80kV(-)（Fig. 8a)に比べ低線量撮影による X線量子ノイズの増加がみられるが，卵管の通過性は 認識できる。また闲写真から子宮・卵管と周辽組織と の画像コントラストに変化はみられない。

\section{2. 考 察}

X線検䍒に扔いて, 線量低滅に有用な手段としては 付㸝フィルタの使用があるが，画質の劣化，装置負街 の上秝を伴う。画質の劣化に対しては，フィル夕の付 加による画像コントラストの低下を管電圧の低下によ って補うことで，コントラストの上昇と線量の低減が 達成できると報告されている(13)，装置負荷の上昇につ いては，CRシステムの㕕いダイナミックレンジによ り，入力信号は常に一定範囲のディジタル值に変換さ れ，最終出力となる写真濃度が撮影条件に左右されず 一定となることから改善される。そこでHSGにおいて CRシステムによる低線量撮影を行った。また，撮影 管電圧と付杊フィルタにより線質を変化させ画像コン トラストを一走に保ち，X線スペクトルの適正化にて 効率よく線量を低減させることについても検討し，両 手法の併用にて大幅な被曝低減を試みた。

低線量撮影した画像の視覚評価を行った結果，S值 が上昇することにより評価は低下したが，これはIPへ の入射X線量が減少し，X線量子ノイズの上犁により 粒状性が低下したことが考えられる1，5，19)。ディジ夕 ルシステムに抏いて線量と画質の関係を考慮すると，
鮮鋭度よりも粒状性が問題になることが多く, 粒状性 を許谷でき，診療情報を損なわない最低限の線量で撮 影すべきであると報告されている1，2．また産婦人科 医によると，HSGは卵管(直径約0.6 mm)に対する造影 剂の通過性が確認できる分解能を有していれば診断上 問題ないとされている。本実験結果にて，模擬卵管が 「なんとか管状に見える」という評価を基準にすると， $\mathrm{S}$ 值1,000１,200の範囲がしきい估となり，解像力千 ヤートの視覚評価ではS值1,200まで一定となった。よ ってS值1,200が低線量撮影できる限界值と考え，基準 条件 $80 \mathrm{kV}(-)$ でのS值500 と低線量撮影によるS值1,200 を比較すると患者皮䖉線量は5 8 \% 低減できた。また解

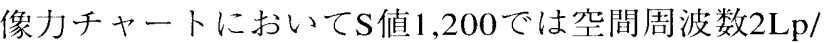
$\mathrm{mm}$ となり，各施設にてHSGを行う際は，管電压一定 にて解像カチャートを撮影し, 空間周波数が $2 \mathrm{Lp} / \mathrm{mm}$ となる撮影条件にて撮影することが望ましいと思われ る。粒状性の低卜に対して，視覚評価に使用した模擬 卵管と解像力チャートによるS值 1,200 の画像の周波数 処理(㓮波数強調度：RE)を変化させて再び視覚評価 した結果，粒状性は改善されたが，検出能はほとんど 変化せず画像コントラストは若干低下した（Fig.9)。

$80 \mathrm{kV} /(-)$ に対して，管電庄を下げフィル夕を付加す ることにより，画像コントラストを一定にすることが できた。これはL值を1.6と低い值に設定し，CRのダ イナミックレンジを狭くしていることが考えられる. 本研究の主旨である大幅な被曝低減を考えると, 管電 圧一定にて付加フィルタの厚さを変化させ，L值によ り画像コントラストを一定にすることが最適であると 考えられるが，L值の調節により画像コントラストを 保つことは不可能であり ${ }^{16)}$ ，また粒状性の低下を招い てしまう。よって本実験では画像コントラスト, 粒状 性を一定にするためし値を変化させずに行った。

撮影時間については，80kV(-)を基準にすると， $72 \mathrm{kV} / 0.3 \mathrm{mmCu}+1 \mathrm{mmAl}$ で3倍, $68 \mathrm{kV} / 0.5 \mathrm{mmCu}$ 
+4mmAlで10傍となった。しかし低線量撮影にてS 值 を1,200にすることにより，それぞれ1.3倍，4.2倍の撮 影時間となった。よってすべての撮影条件に扔いて容 易に臨床適応可能と考えられる。

X線スペクトルにて $76 \mathrm{kV} / 0.1 \mathrm{mmCu}+2 \mathrm{mmAl}$ の撮影 条件は，X線エネルギー41〜66keVの領域で $80 \mathrm{kV} /(-)$ よりも光子検出数が上昇した。 これは付加フィルタ $0.1 \mathrm{mmCu}+2 \mathrm{mmAI}$ の使用によりIP入射線量が減少し, $80 \mathrm{kV} /($-) に対しIP入射線量を一定にするため撮影時間 にて補正しているからであると考えられる。よって， 付加フィルタを使用している他の撮影条件に比べ被写 体に吸収される割合が大きく，被曝低減にとって効率 的ではない.

実効エネルギーは，フィル夕を付加することにより $10 \mathrm{keV}$ 程度上昇し，X線スペクトルでは低エネルギー 成分が大きくカットされたことから被曝低減は可能と なった。しかし線量測定に执いて，ファントム内吸収 線量で72kV/0.3mmCu+1 mmAlより厚いフィルタを付 加してもほとんど変化はなかった。よって, HSGの撮 影条件は, 效率よく低エネルギー成分がカットされる 管電压 $72 \mathrm{kV}$, 付加フィルタ $0.3 \mathrm{mmCu}+1 \mathrm{mmAl}$ の組み 合わせが最適であると考えられる。

HSGにおいて，透視を行い造影剤の流れを観察する ことは，診断能の向上を図るためには重要であり4, 検討した結果，透視条件による視覚評価は， $\mathrm{Cu}$ フィ ルタの使用により低下した。これは実効エネルギーの 上昇により造影剂とアクリルファントムの線減弱係数 の童が小さくなり，被写体コントラストが低下したか らであると考えられる，撮影時の評定法と同様，「な んとか管状に見える」という評価を基準にすると，模 擬卵管 $0.6 \mathrm{~mm}$ では Cuフィル夕0.3mmがしきい值となっ た。

本実験において撮影・透視条件ともに0.3mmのCuフ イルタの使用が最適となり, 患者皮膚線量は撮影条件 で57\%低減でき，透視条件では64\%低減できた。

本研究の主旨は, CRシステムにて低線量撮影を行 い, さらに付加フィルタの使用により大幅な線量低減 を行うことであり，画質に比べ線量低減を重視して撮
影条件を決定した。しかしX線量子ノイズの影站によ り粒状性が低下し画質も劣化した。金州ら" 入射線量が減少し，X線量子ノイズが増大しても，润 像コントラストの上昇が検出率に大きく影響すると報 告している。またCRシステムのL值を上げ，フィルタ の付加を抑えて詷像コントラストを一定とすると，粒 状性が改善され画質も向上する。これらにより基準管 電圧 $80 \mathrm{kV}(-)$ と同等な検出能が得られるかもしれな い.しかし，子宮卵管造影は検査目的から骖断能の搷 なわれない画像を提供し月つ確率的影響のリスクを下 げるためにできる限り線量低減することが重要であ る.よって本研究の有用性は高いと考えられる.

\section{3. 結 語}

1) CRシステムによる低線量撮影を行い, S 值を 1,200まで上昇することができ，患者皮膚線量も $58 \%$ 低減できた。画質は，周波数処理にて粒状 性の改善を行ったが, 変化はみられなかった。

2) 管電圧 $72 \mathrm{kV}$, 付加フィルタ $0.3 \mathrm{mmCu} / 1 \mathrm{mmAl}$ の 組み合わせにより，画像コントラストを一定に保 ち且つX線スペクトルの適正化にて患者支膚線龇 を57\%低減できた。

3) HSGにおいてCRシステムによる低線量撮影と付 加フィルタの使用により，患者皮虑線量を約 82 \%低減でき，検査目的にあった診断能の損なわれ ない画像を提供できることから画質と線量の最適 化が達成されたと言える。また各施設における本 研究の試みは, 解像力チャートの空間周波数が 2Lp/mmまで識別できる撮影条件にて撮影するこ とで達成でき，汎用性に優れていると思われる。

HSGは, 生殖腺 (決定臓器)に対するX線検査である ため，画質よりも線量を重視して撮影条件を決定した が，その他のX線検査においても線量低減と汇質向上: の相反関係をよく理解し, 最適化を実行していくこと が重要である。

本論文の要旨は日本放射線技術学会第47回関東部会 研究発表大会において発表した。 


\section{参考文献}

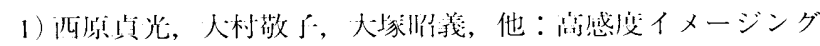
プレートによる被暴の低減一低感度イメージングプレート との比較一。放技学㣟，51(11)，1618-1622，(1995).

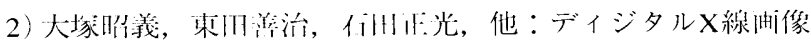

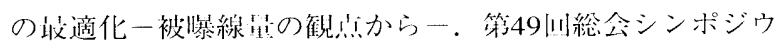
厶, 横浜，1993-4，目本放射線技術学会，目放技学誌，49 (12), 2022-2051, (1993).

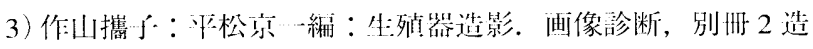
影于:技のポイント，206-209，(1985).

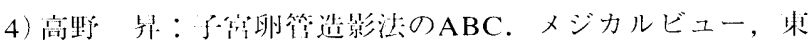
宗，(1997).

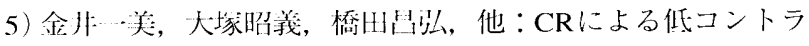

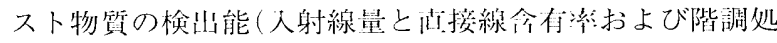
理による虺い)。甘放技学誌，49(4)，570-575，(1993).

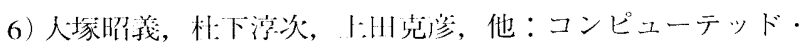
ラジオグラフィ $(\mathrm{CR})$ を川いた低敀乱線掫影注。川放技器 诘，47(4)，610-618，(1991).

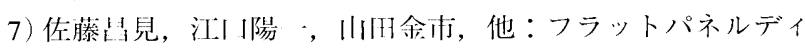
テクタシステムの画像評仙li. 11放技学誌，57(1)，68-77， (2001).

8) 特集：新比糺のデジタルイメージングシステム：FPD. INNERVISION, 16(4)，1-60，(2001).

9) 技術解説：フラットパネルディテクタ (Flat Panel Detector)。 П放技学望，55(8)，735-751，(1999).

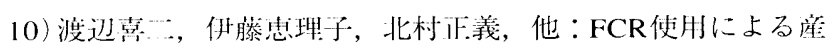

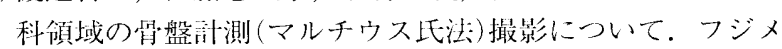
ディカルフォーラム, 143, 15-18,(1984).

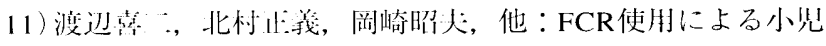
股阐箕掫影について。フジメディカルフォーラム，152， 34-37, (1986).

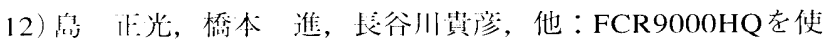

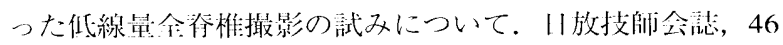
(9), 1125, (1999).

13）不田悦个, 安牛謙一郎, 大塚炤義, 他：X線スペクトルの 適正化による荬質の改善と被暴の低減。日放技学誌, 55 (6), 582-587, (1999).

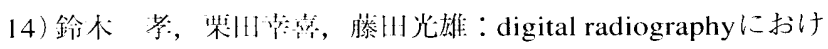
る付加フィルタの份怔性。山放技学誌, 54(12)，13731380, (1998).

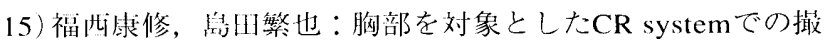
影管電主々付加フィルタの物理特性。 日放技学誌，55 (10), 1018-1025, (1999).

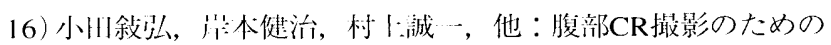
線暨の娭封。 日放技学誌，50(5)，622-629，(1994).

17）辰已大作, I'们順一, 對間博之, 他：CRシステムにおける IPへの入射X線量とS值の関係一均一照射における㳬荲的評 佂一。 田放技学想，54(11)，1273-1280，(1998).

18) Seltzer SM and Hubbell JH : 勈越 久監修: 光子減弱係数 データブック．H本放射線技術学:会, 宗都, (1995).

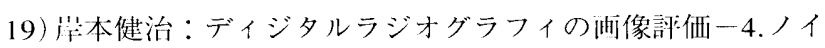
ズ特性１．基礎とCR．第18们秋季学術大会シンポジウ 厶, 䈏川, 1990-11，日本放射線技術学会，日放技学誌， $47(6), 854-858$, (1991).

\section{図表の説明}

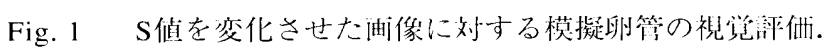

Fig. 2 S 储を変化させた画像に対する解像力チャートの視敩評価.

Fig. 3 管電圧之付加フィルタを組み令わせた摄影条件によるアルミニウムステップの画像コントラスト.

Fig. 4 透視における模擬卵管の視営部㑛.

Fig. 5 管電l:と付加フィルタを組み令わせた攝影条件によるX線スペクトル。

Fig. 6 管電生と付加フィル夕を組み合わせた掫影条件に㧍けるファントム表自とファントム内の吸収線量低減率。

Fig. 7 透視にてCuフィルタによるファントム表面とファントム内の吸収線单低減率.

Fig. 8 80kVフィルタなしと $72 \mathrm{kV} / 0.3 \mathrm{mmCu}+1 \mathrm{mmAl}$ で撮影したボランティアのHSG写真.

Fig. 9 周波数処理した模擬刞管と解像ノチャートの画像に対する視覚部・俩.

Table 1 HSGに使州しているCR処理パラメータ.

Table 2 管電忙と付加フィルタを組み命わせた摄影条件による撮影時間と実効エネルギー.

2001 年 12 月 